Original articles

J. Perinat. Med. 9 (1981) 275

\section{Persistence Time of the Ring of Bubbles (PTRB): A method for the quantification of the Foam Test}

\author{
Eduardo Dávila Aveiga*, Paul Estol**, Hugo Vidal*, Martha Scorza***, \\ Ruben Belitzky****, Raúl Bustos*****, and Roberto Caldeyro-Barcia******
}

Latin American Center of Perinatology and Human Development Pan American Health Organization/World Health Organization Montevideo, Uruguay
* Fellow of the Pan American Health Organization at the Latin American Center of Perinatology and Human Development
** Fellow of the School of Medicine, University of Uruguay
*** Laboratory Technician of the Latin American Center of Perinatology and Human Development
**** Consultant, Pan American Health Organization/World Health Organization
***** Head Neonatologist of the Latin American Center of Perinatology and Human Development
****** Director, Latin American Center of Perinatology and Human Development

\section{Introduction}

Many tests have been developed trying to determine the degree of fetal lung maturity (FLM) [6, $11,12,15]$ to prevent the occurrence of the Respiratory Distress Syndrome (RDS).

The foam test [6] which evaluates the bubble stability of the amniotic fluid, is one of the most used, due to its low cost, its easy performance and its reliable prediction. This test has a high specificity, as a positive result is only very occasionally observed in immature cases. On the other hand, it has a very low sensitivity because mature fetuses are frequently reported as immature $[3,4,5]$.

In samples of amniotic fluid obtained from mature fetuses, the Persistence Time of the Ring of Bubbles (PTRB) is more prolonged than in those
Curriculum vitae

J. EDUARDO DÁVILA AVEIGA was born in Chone, Republic of Ecuador, November 1947. He graduated as Doctor in Medicine and Surgery from the Universidad Central del Ecuador, Quito, in June 1976. He worked as rural doctor for maternal and child health in the province of Manabi (Ecuador) in 1976-1977, and as resident doctor at the Hospital

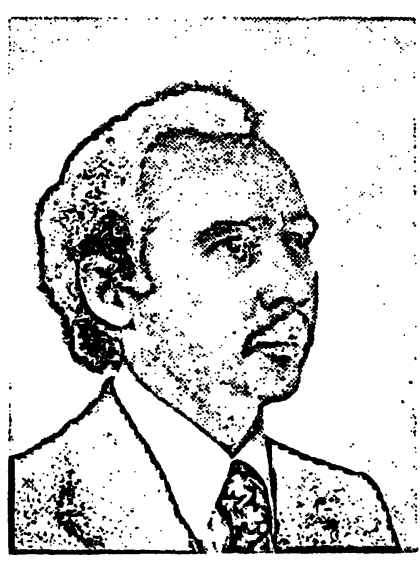
Civil de Chone, in the Maternal-Child Department in 1977-1979. Dr. DA VILA was a fellow at the Latin American Center of Perinatology and Human Development taking the training course on Research in Perinatal Medicine from March 1979 until May 1981. Areas of interest: High risk pregnancy and fetal maturity. 
samples from immature fetuses. This fact led us to postulate the possible existence of a correlation between the PTRB and the quantity and/or quality of surfactant.

The aims of this study are:

- to explore the relationship between the PTRB and the degree of FLM evaluated by the L/S ratio.

- to determine the value of PTRB which allows to discriminate between mature and immature samples by the $\mathrm{L} / \mathrm{S}$ ratio.

- to compare the PTRB and the foam test in their ability to detect those samples reported as mature by the $\mathrm{L} / \mathrm{S}$ ratio.

- to evaluate the PTRB, the foam test and the $\mathrm{L} / \mathrm{S}$ ratio in their ability to determine the degree of FLM, as evidenced by the neonatal outcome.

\section{Material and methods}

A total number of 34 amniocentesis were performed in 23 high risk pregnancies and in 4 normal pregnancies with uncertain dates, without known associated pathology (Tab. I).

Tab. I. Characteristics of the population.

\begin{tabular}{lll}
\hline $\begin{array}{l}\text { Characteristics } \\
\text { of the population }\end{array}$ & $\begin{array}{l}\text { Number } \\
\text { of patients }\end{array}$ & $\begin{array}{l}\text { Number } \\
\text { of samples }\end{array}$ \\
\hline $\begin{array}{ll}\text { Uncertain dates } \\
\text { Diabetes type B and C }\end{array}$ & 4 & 4 \\
Diabetes type D and F & 5 & 8 \\
Chronic hypertension & 2 & 5 \\
Toxemia & 3 & 2 \\
Rh sensitized & 7 & 5 \\
Others & 2 & 8 \\
Total & 27 & 2 \\
\hline
\end{tabular}

None of the studied cases showed clinical or ecographic evidence of polyhydramnios or oligohydramnios. None of the samples were visibly stained with blood or meconium.

The foam test was performed not more than 30 minutes after the extraction of the samples, by the method described by CLEMENTS [6] and modified by the authors [3], as follows: a) Two glass tubes, $150 \mathrm{~mm}$ length and $10 \mathrm{~mm}$ diameter, numbered I and II, were used.

b) The thermic environment was maintained at $25^{\circ} \mathrm{C}$.

c) $1.0 \mathrm{cc}$ of amniotic fluid was placed in tube I and $0.5 \mathrm{cc}$ of amniotic fluid and $0.5 \mathrm{cc}$ of saline, in tube II.

d) $1.0 \mathrm{cc}$ of ethanol $95 \%$ was added to each tube.

e) After covering them with a rubber stopper, both tubes were vigorously and simultaneously shaken with an electric vibrator for 15 seconds.

f) Then both tubes were placed in a vertical rack and left undisturbed.

g) Reading of the results as defined by CLEMENTS [6] was performed after 15 minutes $(900 \mathrm{sec}$ onds).

The result of the test was considered positive when both tubes maintained a continuous ring of bubbles, without interruption of $1 \mathrm{~mm}$ or more. If the ring of bubbles was continuous in tube $I$, and interrupted in tube II, the result was considered as intermediate. The result was negative when the ring of bubbles was interrupted in both tubes.

The persistence time of the ring of bubbles (PTRB) was defined as the time that elapsed since the moment of placing the tubes in the vertical rack (time zero), until the rupture of the ring of bubbles (moment when the ring was interrupted for $1 \mathrm{~mm}$ or more of its circumference).

The PTRB was determined in tube II, since according to the foam test, this tube indicates the separation between the positive (PTRB greater than 900 seconds) and the intermediate and negative results (PTRB less than 900 seconds). A PTRB of more than 900 seconds indicated a positive result by definition. Therefore PTRB was not measured after this time limit.

The L/S ratio was performed by a different technician, as first described by GLUCK [11] and standardized in our laboratory [3].

The diagnosis of RDS was done by a neonatologist who did not know about the results of this research. This diagnosis was based on the following criteria: Grunting, tachypnea, intercostal and sternal retractions and nasal flaring should be present. Symptoms should have persisted for more than 24 hours and oxygen therapy should have been applied. Radiological picture of reticulo- 
granular pattern with or without air bronchograms confirmed the diagnosis.

The sensitivity, specificity and accuracy were determined for each method of FLM diagnosis, as well as the rate of false positives and false negatives.

Sensitivity was considered as the rate of correct diagnosis of mature, in the total mature population. Specificity was considered as the rate of correct diagnosis of immature in the total immature population. Accuracy was the rate of correct diagnosis in the total population. False positives and false negatives were the rates of error in the positive and negative diagnosis, respectively [16]. The data were linearly fitted using the least squares analysis. The level of significance adopted was of $\alpha<0.05$.

\section{Results}

The value of the L/S ratio and the result of the foam test for one sample are seen in Fig. 1. Of the 34 samples, two had a positive foam test result, 12 were intermediate and 20 were negative. The
$\mathrm{L} / \mathrm{S}$ ratio value was equal to or greater than 2.0 in all the samples with positive or intermediate foam test result, and also in 10 of the 20 negative results (50\% of false negative results of the foam test in relation to the $\mathrm{L} / \mathrm{S}$ ratio). Five of these 10 samples were obtained from diabetic mothers type B or C according to WHITE's classification (20). When the total population of samples was considered, the foam test identified the mature ones (L/S ratio equal to or greater than 2.0 ) with a sensitivity of $8.3 \%$, a specificity of $100 \%$ and an accuracy of $35 \%$ (Tab. II).

Tab. II. Prediction of the L/S Ratio by the Foam Test, in the Total Population.

\begin{tabular}{lrrrrr}
\hline Foam test & \multicolumn{2}{l}{ L/S ratio } & Total & \\
& $\geqslant 2.0$ & $<2.0$ & & & \\
\hline Positive & 2 & 0 & 2 & Sensitivity & $8.3 \%$ \\
Intermediate & 12 & 0 & 12 & Specificity & $100.0 \%$ \\
Negative & 10 & 10 & 20 & Accuracy & $35.2 \%$ \\
Total & 24 & 10 & 34 & & \\
\hline
\end{tabular}

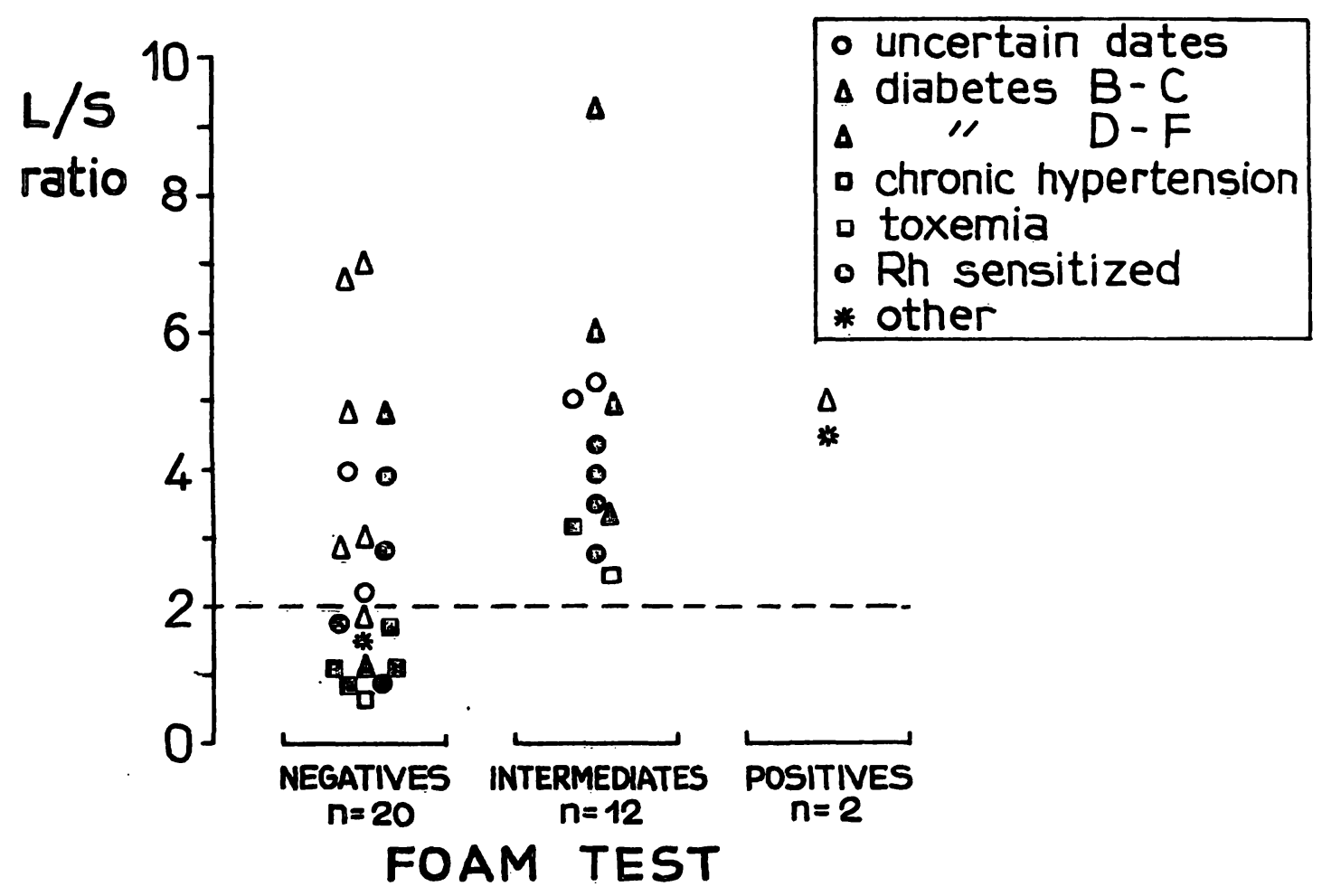

Fig. 1. L/S ratio value and foam test result for each of the 34 samples. An L/S ratio value $\geqslant 2.0$ was found for all samples with a positive or intermediate foam test result, as well as in 10 of the 20 negative results. 
In Fig. 2, the values of the PTRB were plotted according to their respective $\mathrm{L} / \mathrm{S}$ ratio determination, obtained in all 32 samples, with a negative or intermediate foam test result. In those samples with a positive foam test result, the PTRB was not measured as it was greater than 900 seconds. From a general point of view, it can be seen that a greater $\mathrm{L} / \mathrm{S}$ ratio corresponds to a longer PTRB. However, a group of 5 samples differed from the rest of the population. These samples were all obtained from type $\mathrm{B}$ and $\mathrm{C}$ diabetic patients, and had values of $L / S$ ratio greater than 2.0 , with a PTRB of less than 5 seconds.

Excluding the 8 samples that had been obtained from the diabetic patients, a linear correlation was obtained which adjusts to the following linear function: $\mathrm{L} / \mathrm{S}$ ratio $=1.257+0.008 \times \mathrm{PTRB}$, with a correlation coefficient of $r=0.93(p<0.01)$. This line of best adjustment crosses the value of $\mathrm{L} / \mathrm{S}$ ratio $=2.0$ at PTRB of 92 seconds (Fig. 3 ).

A value of 120 seconds of PTRB was thus tentatively adopted as the separation between mature and immature samples; this allows an adequate margin of safety in diagnosis, with a minimum of false positive results. This limit of PTRB was applied to the total population of samples (including those from diabetic mothers type $B$ and $C$ ) and was compared with the limit of 2.0 for the L/S ratio.

It was observed that 15 samples were immature by the PTRB limit (values less than 120 seconds) and 5 of them were mature by L/S ratio, which represents a $33 \%$ incidence of false negatives. In 19 samples with a PTRB equal or greater than 120 seconds, an L/S ratio equal or greater than 2.0 was found in all cases, not presenting any false positives. The sensitivity of the PTRB was established in $79 \%$, its specificity in $100 \%$ and its accuracy in $85 \%$ (Tab. III).

When the 8 samples obtained from types B and C diabetic mothers were excluded from this comparison, the sensitivity and accuracy improved to $100 \%$, as all false negatives were thus excluded (Tab. IV).

In 24 cases of the total population of this study, the last sample of amniotic fluid was obtained during the four days before delivery. RDS was diagnosed in 5 cases. The foam test identified only
Tab. III. Prediction of the $L / S$ iRatio by the PTRB, in the Total Population.

\begin{tabular}{lrrrrr}
\hline PTRB & \multicolumn{3}{l}{ L/S ratio } & \multicolumn{2}{l}{ Total } \\
& $\geqslant 2.0$ & $<2.0$ & & \\
\hline$\geqslant 120$ seconds & 19 & 0 & 19 & Sensitivity & $79.0 \%$ \\
$<120$ seconds & 5 & 10 & 15 & Specificity & $100.0 \%$ \\
& & & & Accuracy & $85.0 \%$ \\
Total & 24 & 10 & 34 & & \\
\hline
\end{tabular}

Tab. IV. Prediction of the L/S Ratio by the PTRB, when Types B and C Diabetics are excluded.

\begin{tabular}{lrrrrr}
\hline PTRB & \multicolumn{3}{l}{ L/S ratio } & Total & \\
& $\geqslant 2.0$ & $<2.0$ & & \\
\hline$\geqslant 120$ seconds & 17 & 0 & 17 & Sensivity $100.0 \%$ \\
$<120$ seconds & 0 & 9 & 9 & $\begin{array}{l}\text { Specificity } 100.0 \% \\
\text { Accuracy }\end{array} 100.0 \%$ \\
Total & 17 & 9 & 26 & & \\
\hline
\end{tabular}

two of the 19 cases that did not develop RDS, representing a sensitivity of $10.5 \%$, whereas all five neonates that did develop RDS were identified as negatives. Thus, specificity was $100 \%$. The accuracy was $29 \%$ (Tab. V).

Tab. V. Prediction of the Neonatal Outcome by the Foam Test, in the Total Population.

\begin{tabular}{lrrrrr}
\hline Foam test & \multicolumn{2}{c}{ RDS } & \multicolumn{3}{l}{ Total } \\
& No & Yes & & & \\
\hline Positive & 2 & 0 & 2 & Sensitivity & $10.5 \%$ \\
Intermediate & 11 & 0 & 11 & Specificity $100.0 \%$ \\
Negative & 6 & 5 & 11 & Accuracy & $29.0 \%$ \\
Total & 19 & 5 & 24 & $\ldots$ & \\
\hline
\end{tabular}

The L/S ratio identified all the cases which did not suffer RDS (sensitivity of $100 \%$ ), whereas its specificity was $80 \%$ due to one case classified as mature by the L/S ratio that developed RDS (5\% 


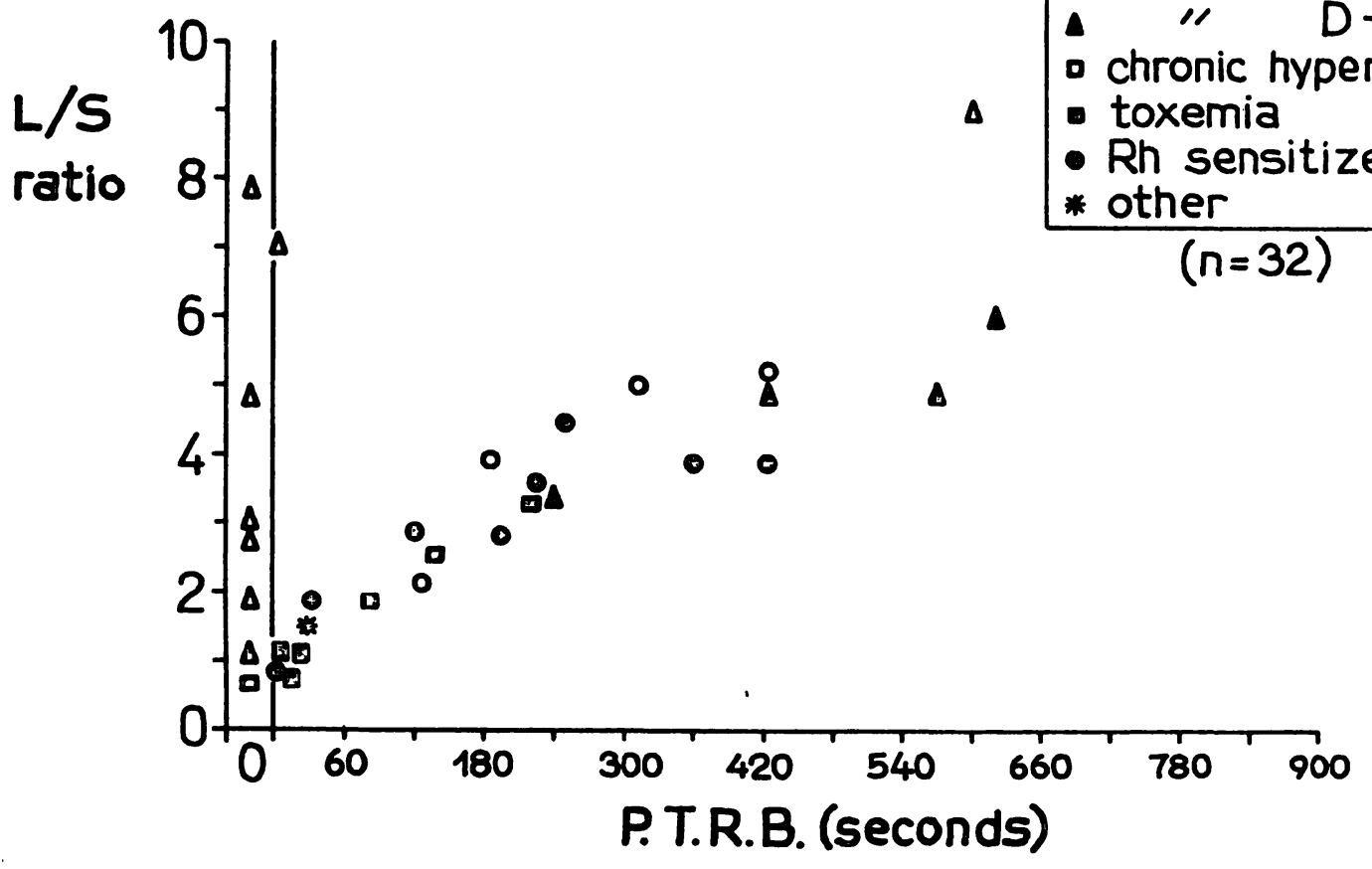

Fig. 2. PTRB values of all 32 samples with a negative or intermediate foam test result, are plotted according to their respective $\mathrm{L} / \mathrm{S}$ ratio values. A greater $\mathrm{L} / \mathrm{S}$ ratio corresponds to a longer PTRB. However a group of 5 samples obtained from type B and C diabetics had a L/S ratio higher than 2.0 with a PTRB of less than 5 seconds.

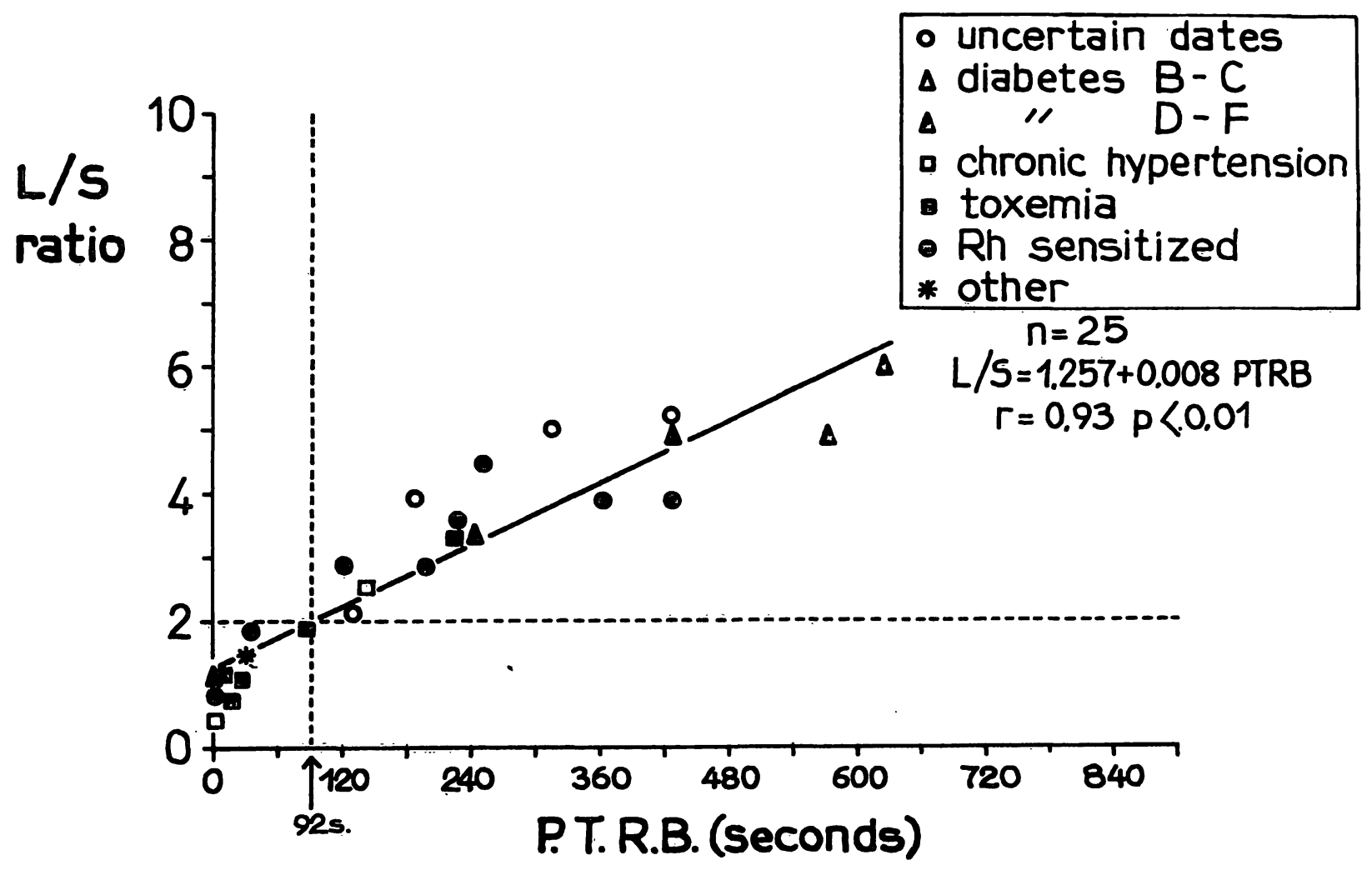

Fig. 3. Linear correlation obtained between the PTRB and the L/S ratio values for each sample when $B$ and $C$ diabetics are excluded. The line so defined intercepts the $L / S$ ratio value of 2.0 with a PTRB value of 92 seconds. 
of false positives) (Fig. 4). The accuracy was $95.8 \%$ (Tab. VI).

Tab. VI. Prediction of the Neonatal Outcome by the L/S Ratio, in the Total Population.

\begin{tabular}{lccrl}
\hline L/S ratio & RDS & \multicolumn{3}{c}{ Total } \\
& No & Yes & & \\
\hline$\geqslant 2.0$ & 19 & 1 & 20 & Sensitivity $100.0 \%$ \\
$<2.0$ & 0 & 4 & 4 & Specificity $80.0 \%$ \\
& & & & Accuracy $95.8 \%$ \\
Total & 19 & 5 & 24 & \\
\hline
\end{tabular}

When the value of PTRB was equal or greater than 120 seconds, none of the 18 neonates developed RDS (Fig. 4). When PTRB was below 120 seconds (6 cases), five of these neonates developed RDS; the sensitivity of this method was $95 \%$ because only one case was a false negative (16.6\%). Its specificity was $100 \%$ and its accuracy $96 \%$ (Tab. VII).

Tab. VII. Prediction of the Neonatal Outcome by the PTRB, in the Total Population.

\begin{tabular}{lrrrrr}
\hline PTRB & \multicolumn{3}{l}{ RDS } & \multicolumn{2}{l}{ Total } \\
& No & Yes & & & \\
\hline$\geqslant 120$ seconds & 18 & 0 & 18 & Sensitivity & $94.7 \%$ \\
$<120$ seconds & 1 & 5 & 6 & Specificity $100.0 \%$ \\
& & & & Accuracy & $95.8 \%$ \\
Total & 19 & 5 & 24 & & \\
\hline
\end{tabular}

When neonates of diabetic type $B$ and $C$ mothers are excluded, all four cases with a PTRB of less than 120 seconds developed RDS. The other 16 cases which had a PTRB value equal or greater than 120 seconds, did not develop RDS. The sensitivity, specificity and accuracy of the PTRB

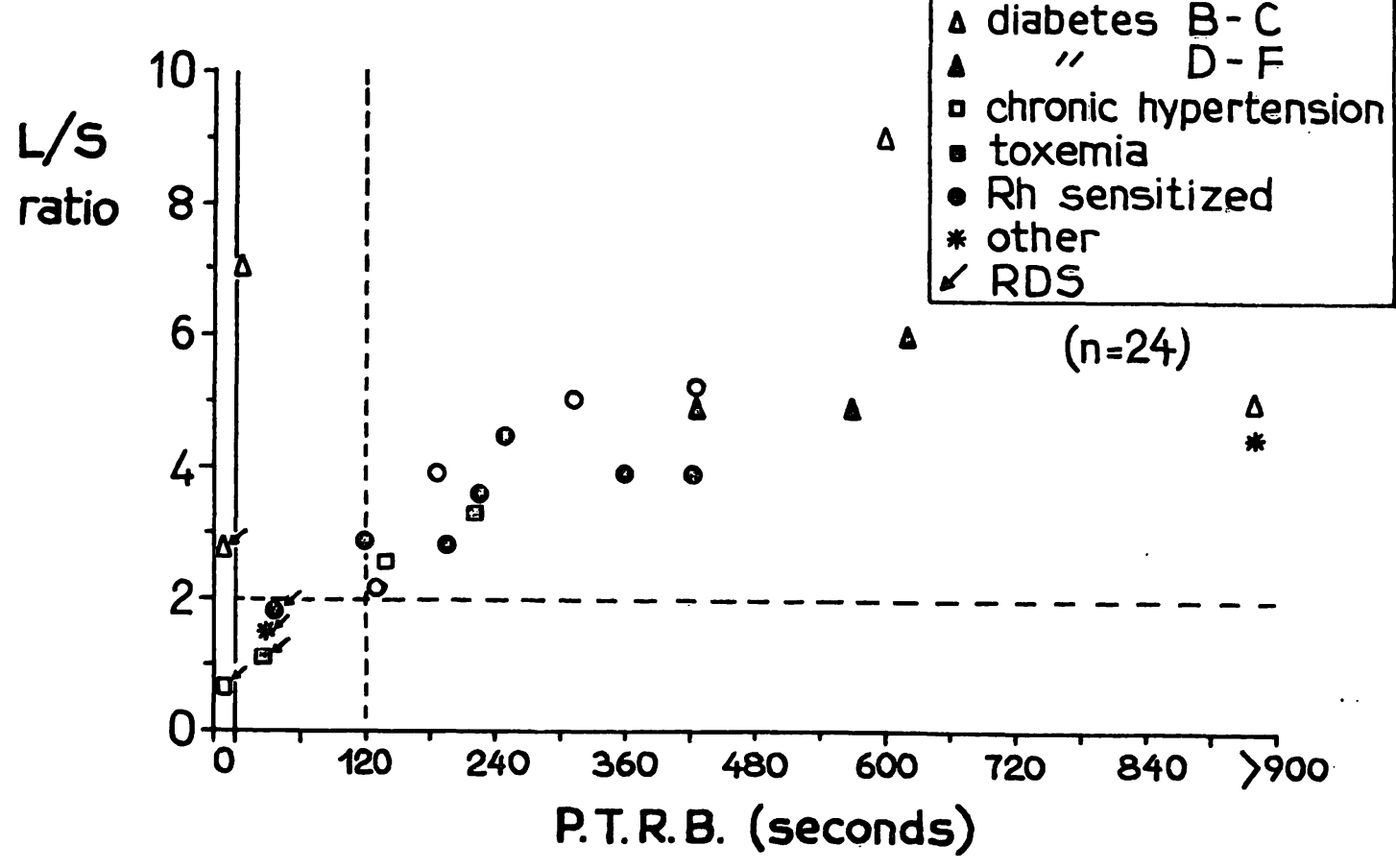

Fig. 4. PTRB and L/S ratio values of samples obtained from 24 cases during the four days prior to delivery. The 5 cases in which RDS was diagnosed had a PTRB value of less than 120 seconds; four of them had an L/S ratio $<2.0$, and one was greater than 2.0. All cases with a PTRB $\geqslant 120$ seconds did not develop RDS. 
method reached $100 \%$ when the types $B$ and $C$ diabetic pregnancies were excluded (Tab. VIII).

Tab. VIII. Prediction of the Neonatal Outcome by the PTRB, when Types B and C Diabetics are excluded.

\begin{tabular}{lrrrr}
\hline PTRB & \multicolumn{3}{l}{ RDS } & \multicolumn{2}{l}{ Total } \\
& No & Yes & & \\
\hline$\geqslant 120$ seconds & 16 & 0 & 16 & Sensitivity 100.0\% \\
$<120$ seconds & 0 & 4 & 4 & Specificity 100.0\% \\
& & & & Accuracy 100.0\% \\
Total & 16 & 4 & 20 & \\
\hline
\end{tabular}

\section{Discussion}

The correlation found between the PTRB and the $\mathrm{L} / \mathrm{S}$ ratio enabled the determination of a PTRB value (120 seconds) that could be taken as a limit between mature and immature, according to the $\mathrm{L} / \mathrm{S}$ ratio. This PTRB value was more accurate in discriminating the matures and immatures according to the L/S ratio, when compared with the foam test. It was also more accurate in discriminating matures and immatures according to the neonatal outcome, when compared with the foam test and the $\mathrm{L} / \mathrm{S}$ ratio, respectively.

When the PTRB and the foam test were compared with the $\mathrm{L} / \mathrm{S}$ ratio taking the value of 2.0 as limit of maturity, the first test seemed to be a good indicator of FLM since it was more sensitive and of similar specificity as the foam test. The advantage of the PTRB consisted in its capacity for identifying as mature, the group of the so-called "intermediates" according to the foam test, as well as a large proportion of its false negatives.

Since all the false negative results of the PTRB were found in the diabetic type $B$ and $C$ patients, this test would not be appropriate in these cases. When the samples from diabetic type B and C patients were excluded, the value of 120 seconds of PTRB discriminated the matures from the immatures with an accuracy of $100 \%$, whatever the indicator of FLM used, L/S ratio or neonatal outcome.

The PTRB discriminated the matures by the L/S ratio from the total population (including diabetic patients) with a higher degree of sensitivity than the foam test. The foam test showed a $50 \%$ rate of false negatives in relation to the $L / S$ ratio. The PTRB for these same samples had $33 \%$ of false negatives. Thus, by using the PTRB instead of the foam test in this population, the rate of false negatives was reduced by $17 \%$.

The rate of false negatives of the foam test in relation to the L/S ratio obtained in this study was higher than that shown in our previous work [3]. This could be due to a larger proportion of samples obtained from type $\mathrm{B}$ and $\mathrm{C}$ diabetics in the present study.

In the prediction of the neonatal outcome, the results obtained from the total population should be considered separately from those obtained by excluding the samples of type $B$ and $C$ diabetics.

When the total population was considered, the methods of greater specificity were the foam test and the PTRB, whereas the L/S ratio showed a lower specificity due to the appearance of one false positive case. This only false positive result of the $\mathrm{L} / \mathrm{S}$ ratio, was found in a neonate born from a diabetic type $\mathrm{C}$ mother. The $\mathrm{L} / \mathrm{S}$ ratio value was 2.7 and the newborn developed a moderate RDS, which had a good evolution, recovering in three days.

The appearance of false positive results in the $\mathrm{L} / \mathrm{S}$ ratio of the diabetic population has already been mentioned by other investigators $[1,7,9,17,19]$ and is, at present, one of the major unsolved problems in the field of FLM.

The sensitivity of the foam test was very low $(10.5 \%)$, as compared with the high rate in the PTRB (95\%), similar to that reached by the L/S ratio $(100 \%)$. The results of the PTRB improved when type $B$ and $C$ diabetic patients were excluded, sensitivity reaching $100 \%$.

Despite these encouraging results, we believe that a larger number of samples should be studied before reaching final conclusions about this new method.

The different results obtained from the amniotic fluids of type $B$ and $C$ diabetics, as compared to the rest of the study population, may suggest possible alterations in amniotic fluid tensoactive properties, not followed by modifications in the L/S ratio. This could be explained by an amniotic 
fluid dilution in these patients, or by some alteration of the tensoactive properties of surfactant, not reflected in the $\mathrm{L} / \mathrm{S}$ ratio. Perhaps this could be associated to altered water metabolism of amniotic fluid, which could be related to the higher incidence of polyhydramnios in these cases $[13,14]$. It could also be associated with some defect in the synthesis of the pulmonary surfactant complex, possibly related to the hyperinsulinism of these fetuses $[10,18]$. The fact that the only false positive of the $L / S$ ratio came from a type $C$ diabetic patient could support this last explanation.

However, the results obtained from the 5 samples of type $D$ and $F$ diabetics were similar to those of the rest of the population, "but quite different from those of type $B$ and $C$ diabetics. We ignore the behavior of type A diabetics, as no case was included in our study.

As a conclusion, we may state that the PTRB is a modification of the foam test, that allows a better quantification by reducing the rate of false negatives and apparently clearing doubts on the "intermediate" results of this test. The test also shows different characteristics in samples from type B and $C$ diabetic patients, which would require the use of a different method for the determination of FLM in these patients, for example, the determination of phosphatidylglycerol $[1,2,8,15]$.

and $C$ diabetic patients, and had values of $L / S$ ratio greater than 2.0, with a PTRB of less than 5 seconds.

Excluding the 8 samples that had been obtained from the diabetic patients, a linear correlation was obtained which adjusts to the following linear function: $\mathrm{L} / \mathrm{S}$ ratio $=1.257$ $+0.008 \times$ PTRB, with a correlation coefficient of $r=0.93$ (p $<0.01$ ).

A value of 120 seconds of PTRB was thus tentatively adopted as the separation between mature and immature samples; this allows an adequate margin of safety in diagnosis, with a minimum of false positive results.

It was observed that 15 samples were immature by the PTRB limit (values less than 120 seconds) and 5 of them were mature by L/S ratio, which represents a $33 \%$ incidence of false negatives. In 19 samples with a PTRB equal or greater than 120 seconds, an L/S ratio equal or greater than 2.0 was found in all cases, not presenting any false positives.

When the 8 samples obtained from diabetic types $B$ and $C$ mothers were excluded from this comparison, the sensitivity and accuracy improved to $100 \%$, as all false negatives were thus excluded (Tab. IV).

In 24 cases of the total population of this study, the last sample of amniotic fluid was obtained during the four days before delivery. RDS was diagnosed in 5 cases.

When the value of PTRB was equal or greater than 120 seconds, none of the 18 neonates developed RDS. When PTRB was below 120 seconds (6 cases), five of these neonates developed RDS; the sensitivity of this method was $95 \%$ because only one case was a false negative $(16.6 \%)$. Its specificity was $100 \%$ and its accuracy $96 \%$ (Tab. VII). When neonates of diabetic type $B$ and $C$ mothers are excluded, all four cases with a PTRB of less than 120 seconds developed RDS. The other 16 cases which had a PTRB value equal or greater than 120 seconds, did not develop RDS. The sensitivity, specificity and accuracy of the PTRB method reached $100 \%$ when the diabetic types $B$ and $C$ pregnancies were excluded (Tab. VIII). 
The advantage of the PTRB consisted in its capacity for identifying as mature, the group of the so-called "intermediates" according to the foam test, as well as a large proportion of its false negatives. Since all the false negative results of the PTRB were found in the diabetic type B and $C$ patients, this test would not be appropriate in these cases.
As a conclusion, we may state that the PTRB is a modification of the foam test, that allows a better quantification by reducing the rate of false negatives and apparently clearing doubts on the "intermediate" results of this test.

Keywords: Amniotic fluid, diabetic pregnancy, fetal lung maturity, foam test, high risk pregnancy, L/S ratio.

\section{Zusammenfassung}

Dauer des Blasenringes (DBR). Eine Quantifizierung des Foam Testes

Verschiedene Tests wurden entwickelt, um den Grad der foetalen Lungenreife (FLR) zu bestimmen, zur Verhütung des Auftretens des Atemnotsyndroms (ANS).

Der Foam Test, der die Blasenstabilität der Amnionflüssigkeit bestimmt, wird am meisten angewendet, weil er so billig, einfach in der Durchführung und zuverlässig ist. Die (DBR) ist länger in Fruchtwasserproben von reifen Neugeborenen als von Frühgeborenen. Daraufhin vermuten wir eine mögliche Korrelation zwischen der DBR und die Menge und/oder die Qualität des Surfactants, gemessen an der L/S Ratio und dem Neonatal-Befinden. 34 Fruchtwasserpunktionen wurden in 23 Risikoschwangerschaften und in 4 normalen Schwangerschaften mit Terminunsicherheiten durchgeführt (Tab. I). Der FoamTest wurde 30 min nach der Punktion mit der von den Autoren modifizierten CLEMENTS'sche Methode bestimmt. Als DBR wurde der Zeitraum genommen zwischen dem Hinstellen der F-W-Proben in einen vertikalen Ständer und das Platzen des Blasenrings (Bruch $\geqslant 1 \mathrm{~mm}$ des Umfanges). Die L/S Ratio erfolgte durch eine standardisierte GLUCK'sche Methode. Die Diagnose, eine ANS, wurde durch einen Neonatalogen gestellt, der nicht über die Untersuchungsergebnisse informiert war.

Die Empfindlichkeit, Spezifität und Genauigkeit wurde für jede Methode zur Diagnose einer FLR festgestellt, ebenso wie die falsch positiven und falsch negativen $\mathrm{Be}-$ funde. Die DBR-Werte wurden mit übereinstimmenden L/S Ratio der 32 negativen oder zweifelhaften FoamTest-Ergebnisse verglichen (Fig. 2).

Mit einer höheren L/S Ratio stimmte eine längere DBR überein, außer in 5 Fällen. Diese 5 Proben kamen von schwangeren Diabetici - Type B und C - und hatten eine L/S Ratio $>2$ bei einer $\mathrm{DBR}<5 \mathrm{sec}$. Wenn man die 8 Proben der Diabetici wegläßt, bekommt man folgende lineare Formel: L/S Ratio $=1,257+0,008 \times \mathrm{DBR}$; Korrelationsfaktor $r=0,93(P<0,01)$.

Ein DBR-Wert von 120 sec. wurde empirisch angenommen als Grenze zwischen reifen und unreifen Proben.
Hiermit ist die Diagnose mit einem ausreichenden Sicherheitsbereich und einem Minimum an falsch negativen Befunden möglich. Von den 15 unreifen Proben im DBR ( $120 \mathrm{sec}$ ) waren 5 reif im L/S-Test, was einer 33\%-Inzidenz von falsch negativen Werten entspricht. Von den 19 Proben mit einem DBR $\geqslant 120 \mathrm{sec}$ war die L/S Ratio immer $\geqslant 2,0$, d.h. keine falsch positiven $\mathrm{Er}$ gebnisse.

Wenn man die 8 Proben der Schwangeren-Diabetici Typ B und C - aus dieser Vergleichsstudie weglassen würde, würde die Empfindlichkeit und Genauigkeit auf $100 \%$ ansteigen, da dann alle falsch negativen Werte ausgeschlossen werden (Tab. IV). In den 24 Fällen dieser Studie wurde die letzte Fruchtwasserpunktion 4 Tage vor der Entbindung durchgeführt. Eine ANS wurde in 5 Fällen diagnostiziert. Bei einem DBR $\geqslant 120 \mathrm{sec}$ entwickelte keines der 18 Neugeborenen ein ANS. Die Empfindlichkeit der Methode betrug $95 \%$, da es nur einen falsch negativen Befund gab $(16,6 \%)$. Die Spezifität betrug $100 \%$ und die Genauigkeit 96\% (Tab. VII). Wenn man die Neugeborenen der Diabetici - Typen B und C nicht mitrechnet, entwickelten alle 4 Patienten mit einem DBR < 120 sec. ein ANS. Die 16 anderen Fälle mit einem DBR $\geqslant 120$ sec entwickelten kein ANS. Die Empfindlichkeit, Spezifität und Genauigkeit erreichten $100 \%$, wenn die diabetischen Schwangeren - Typen B und $C$ - aus der Studie ausgelassen wurden (Tab. VIII). Der Vorteil der DBR liegt in der Möglichkeit, die reifen Patienten aus den zweifelhaften und falsch negativen Foam-Test-Ergebnissen herauszufinden. Da alle falschnegativen Befunde im DBR-Test schwangere Diabetici Typen B und C - sind, ist der Test in diesen Fällen nicht geeignet.

Zusammenfassend kann man sagen, daß der DBR-Test ein modifizierter Foam-Test ist, mit dem man die falsch negative Zahl reduziert und die zweifelhaften Befunde weiter aufschlüsseln kann.

Schlüsselwörter: Foam-Test, Foetale Lungenreife, Fruchtwasser, L/S Ratio, Risikoschwangerschaft, Schwangere Diabetici.

\section{Résumé}

Le temps de persistence de la circonférence de la bulle (TPCB). Une methode de quantification du foam test Plusieurs tests ont été développés en vue de déterminer le degré de maturité pulmonaire foetale (MPF), pour pré- venir le syndrome de membranes hyalines (SMH).

Le foam test avec lequel on evalue la stabilité des bulles de liquide amniotique est un des plus utilisés parcequ'il n'est pas cher, simple à effectuer et donne de bons résul- 
tats. Les échantillons de liquide amniotique obtenus de foetus arrivés à maturité avaient un TPCB plus long que les échantillons prélevés sur des foetus immatures.

Le fait a permis de postuler l'existence possible d'une corrélation entre le TPCB et la quantité et/ou la qualité du surfactant, evaluée selon le rapport $\mathrm{L} / \mathrm{S}$ et le résultat néonatal. Un nombre total de 34 ponctions amniotiques ont été éffectuées dans 23 cas de grossesses à haut risque et dans 4 grossesses normales avec date d'accouchement incertain sans pathologie associée (Tab. I). Le foam test était éffectué moins de $30 \mathrm{~min}$ après la ponction, selon la méthode décrite par CLEMENTS et modifiée par les auteurs. Le TPCB était défini comme le temps entre le moment de l'éclatement (rupture $\geqslant 1 \mathrm{~mm}$ de la circonférence) et le moment ou le tube était placé verticalement dans le support (= temps zero). Le rapport $\mathrm{L} / \mathrm{S}$ était éffectué par un autre technicien selon la méthode décrite par GLUCK et standardisée dans notre laboratoire. La diagnose du SMH était fait par un néonatologiste n'ayant pas connaissance des résultats de cette recherche.

La sensibilité, la spécificité et la précision étaient déterminées pour chaque méthode de diagnose de MPF, aussi bien que pour les pourcentages des faux négatifs et des faux positifs. Les valeurs du TPCB étaient raportées en relation avec leurs rapport $\mathrm{L} / \mathrm{S}$ respectifs sur un graphique pour les 32 échantillons dont le foam test était négatif ou intermédiaire (Fig. 2). Un grand rapport L/S correspond à un long TPCB excepté dans 5 cas. Tous ces 5 échantillons provenaient de patientes diabétiques type $B$ et $C-$ et avaient un rapport $L / S>2$ ainsi un TPCB $<5$ sec. En exclusant ces 8 échantillons provenant de patientes diabétiques une corrélation linéaire pouvait être obtenue en ajustant la fonction linéaire suivante: Rapport $L / S=1,257+0,008 \times$ TPCB avec le coëfficient de correlation $\mathrm{r}=0,93(\mathrm{P}<0,01)$.

Une valeur de 120 sec de TPCR fut adoptée de façon empirique pour séparer les échantillons matures et imma- tures. Ceci permit une diagílose avec marge de sécurité suffisante et avec un minimum de résultats faussement positifs. On observa que de 15 échantillons immatures pour la TPCB $<120 \mathrm{sec}) 5$ avaient un rapport L/S mature; ce qui représente une incidence de $33 \%$ de faux négatifs. Pour 19 échantillons ayant un TPCB $\geqslant 120 \mathrm{sec}$ le rapport $\mathrm{L} / \mathrm{S}$ était $\geqslant 2$ dans tous les cas; donc ne présentant aucun faux positif quand on excluait les 8 échantillons obtenus de mères diabétiques type $\mathrm{B}$ et $\mathrm{C}-$ de cette comparaison, la sensibilité et la sécurité avoisinaient les $100 \%$ parce que tout les faux négatifs étaient exclus (Tab. IV). Dans les 24 cas de cette étude, la dernière prise d'échantillon amniotique était prélevée pendant les 4 derniers jours de la grossesse. Le SMH était diagnostiquéé dans 5 cas. Lorsque la valeur de TPCR $\geqslant 120 \mathrm{sec}$ aucun des 18 nouveau-nés ne présentait un SMH. Lorsque le TPCB $<120 \mathrm{sec}$ (6 cas) 5 nouveau-nés développaient un SMH. La sensibilité de cette méthode était de $95 \%$ parce que un cas était faux négatif $(16,6 \%)$. La spécificité était de $100 \%$ et la précision de $96 \%$ (Táb. VII).

Lorsqu'on exclu les nouveau-nés des mères diabétiques type $B$ et $C-$ les 4 cas avec un TPDB $<120$ sec dévéloppaient un SMH. Les 16 autres cas ayant un TPDB $\geqslant 120$ sec ne dévelöppaient pas le SMH. La sensibilité, la spécificité et la précision atteignaient $100 \%$ quand on excluait les diabétiques enceintes - type B et C (Tab. VIII). L'avantage de la méthode du TPDB consiste dans ša possibilité de découvrir les patients matures parmi le groupe des intermédiaires et dans les faux négatifs du foam test. Parce que tous les faux négatifs du TPDB ont été trouvés chez les patientes diabétiques - type B et $C$ - ce test ne peut être utilisé dans ces cas.

Comme conclusion on peut dire que le TPDB est une modification du foam test qui permet une meilleure quantification par réduction des faux négatifs et apparemment écarte les doutes des résultats intermédiaires.

Mots-clés: Foam test, grossesse à haut risque, liquide amniotique, maturité pulmonaire foetale, parturiente diabétique, rapport $\mathrm{L} / \mathrm{S}$.

Acknowledgement: The authors wish to thank Mrs. DORIS STINGL DE PALUMBO for her help in the preparation of the manuscript as well as Eng. FRANCO SIMINI for his technical assistance in the biostatistical analysis and study of the diagnostic value of the tests.

Bibliography

[1] BENT, A., J. GRAY, E. LUTHER, M. OULTON, L. PEDDLE: Phosphatidylglycerol determination on amniotic fluid $10.000 \mathrm{xg}$ pellet in the prediction of fetal lung maturity. Amer. J. Obstet. Gynec. 139 (1981) 259

[2] BUSTOS, R., M. KULOVICH, L. GLUCK, G. GABBE, L. EVERSTON, C. VARGAS, E. LOWENBERG: Significance of phosphatidylglycerol in amniotic fluid in complicated pregnancies. Amer. J. Obstet. Gynec. 133 (1979) 899

[3] BUSTOS, R., G. GIUSSI, J. VINACUR, P. DUHAGON, R. MAGRI, J. XERCAVINS, C. CABALLERO, R. ROSAS: Determination of fetal lung maturity by $\mathrm{L} / \mathrm{S}$ ratio, shake test and phosphatidylglycerol in amniotic fluid. J. Perinat. Med. 7 (1979) 79

[4] Bustos, R., P. estol, A. Fasanello, M. SCORZA, G. GIUSSI: Optical density at $650 \mathrm{~nm}$ in amniotic fluid, $\mathrm{L} / \mathrm{S}$ ratio and foam test as indicators of fetal lung maturity. J. Perinat. Med. 8 (1980) 278

[5] CASPI, E., P. SCHREYER, I. TAMIR: The amniotic fluid foam test, $L / S$ ratio and total phospholipids in the evaluation of fetal lung maturity. Amer. J. Obstet. Gynec. 122 (1973) 323

[6] CLEMENTS, J. A., C. G. PLATZKer, D. F. TIERNEY, C. J. HOBEL, R. K. CREASY, A. J. MAR- 
GOLLIS, D. W. THIBAULT, W. H. TOOLEY, W. $\mathrm{OH}$ : Assessment of the risk of the respiratory distress syndrome by a rapid test for surfactant in amniotic fluid. New Engl. J. Med. 286 (1972) 1077

[7] CRUZ, A. C., W. C. BUHI, S. A. BIRK, W. N. SPELLACY: Respiratory Distress Syndrome with mature L/S ratios: Diabetes mellitus and low Apgar scores. Amer. J. Obstet. Gynec. 126 (1976) 78

[8] CUNNINGHAM, D. J., N. DESAI, S. THOMPSON, J. GREENE: Amniotic fluid phosphatidylglycerol in diabetic pregnancy. Amer. J. Obstet. Gynec. 131 (1978) 719

[9] DONALD, L. R., R. K. FREEMAN, U. GOEBELSMAN, W. H. CHAN, R. M. NAKAMURA: Clinical experience with the amniotic fluid L/S ratio. I. Antenatal prediction of pulmonary maturity. Amer. J. Obstet. Gynec. 115 (1973) 547

[10] DRAISEY, T. F., G. L. GA GNEJA, R. J. THIBERT: Pulmonary surfactant and amniotic fluid insulin. Obstet. and Gynec. 50 (1977) 197

[11] GLUCK, L., M. KULOVICH, R. BORER, P. BRENNER, G. ANDERSON, W. SPELLACY: Diagnosis of the respiratory distress syndrome by amniocentesis. Amer. J. Obstet. Gynec. 109 (1971) 440

[1.2] GONEN, R., J. TAL, M. OETTINGER, I. SAMBERG, M. SHARF, H. YECHIELI, J. BOXER: Assessment of fetal lung maturity by a microviscosimeter. Obstet. and Gynec. 51 (1978) 422

[13] JACOBY, H. E., D. CHARLES: Clinical conditions associated with hydramnios. Amer. J. Obstet. Gynec. 94 (1966) 910
[14] KITZMiller, J., J. CLOHERTY, M. YOUNGER, A. TABATABAII, S. ROTHCHILD, I. SOSENKO, M. EPSTEIN, S. SINGH, R. NEFF: Diabetic pregnancy and perinatal morbidity. Amer. J. Obstet. Gynec. 131 (1978) 560

[15] KULOVICH, M., L. GLUCK: The lung profile. II. Complicated pregnancy. Amer. J. Obstet. Gynec. 135 (1979) 64

[16] MCNEIL, B. J., S. J. ADELSTEIN: Determining the value of diagnostic tests and screening tests. J. Nucl. Med. 17 (1976) 439

[17] MUEller-HeUbACH, E., S. N. CARITIS, D. I. EDELSTONE, J. H. TURNER: L/S ratio in amniotic fluid and its value for the prediction of neonatal RDS in pregnant diabetic women. Amer. J. Obstet. Gynec. 130 (1978) 26

[18] SMITH, B. T., C. J. P. GIROUd, M. ROBERT, M. E. AVERY: Insulin antagonism of cortisol action on lecithin synthesis by cultured fetal lung cells. J. Pediat. 87 (1975) 953

[19] TCHOBOURSKY, C., C. AMIEL-TISON, L. CEDARD, E. ESCHWEGE, J. L. ROUVILLOIS, G. TCHOBROUSKY: The $\mathrm{L} / \mathrm{S}$ ratio in 132 insulin dependent pregnancies. Amer. J. Obstet. Gynec. 130 (1978) 754

[20] WhITE, P., P. Koshy, J. DUCKERS: The management of pregnancy complicating diabetes and of children of diabetic mothers. Med. Clin. N. Amer. 37 (1953) 1481

Received May 18, 1981. Accepted July 17, 1981.

Dr. Raúl Bustos

Casilla de correo 627

Montevideo, Uruguay

Casilla de correo 627

Montevideo, Uruguay 